\title{
CHALLENGES FOR SAFETY SCIENCES AND EDUCATION IN THE LIGHT OF THE CURRENT EXPERIENCE WITH THE COVID-19 PANDEMIC
}

\section{Original article}

Accepted: September 2020

Published: November 2020

Peer review:

Double blind

Keywords:

COVID-19 pandemic, consequences of the COVID-19 pandemic, health safety, health safety culture, education for safety

This work is licensed under the Creative Commons AttributionNonCommercial-NoDerivatives 4.0 License

\author{
Marian Cieślarczyk \\ ORCID - 0000-0002-3382-8168 \\ Military University of Technology in Warsaw, \\ gen. Sylwestra Kaliskiego 2, 01-476 Warszawa
}

\begin{abstract}
The subject of the research conducted for the purpose of this article was the crisis generated by the COVID-19 pandemic, which continues to spread around the world. An attempt was made to define the current and anticipated consequences of the pandemic in terms of several areas of the broadly understood concept of safety.
\end{abstract}

Purpose: The purpose of the article was to present one of the possible methods for examination of the multidimensional safety problems generated by the pandemic at a national and international level.

Method: The article was prepared using a problem-based approach and elements of the heuristic method: the new look method and the analogue method. The research part was, in turn, based on critical document analysis.

Results: The article demonstrates the possibilities offered by a holistic research perspective and the need for an inter- and transdisciplinary approach. On the basis of the current experience with the pandemic, several theoretical models were suggested for examining the consequences of COVID-19 and prepare for similar challenges in the future. The applicability of these models was previously tested empirically in relation to the crisis management system in Poland.

Conclusions: The conclusions may have cognitive and practical value, especially in relation to safety systems and the related subsystem of health safety, as well as for education. 


\section{Introduction to the problem}

Although it has already been several months since the outbreak of the COVID-19 pandemic was announced, the war with the coronavirus continues. In the second half of 2020, it is still known when it will end and what consequences it will have, both in terms of shortterms and long-term effects. What is known, at this stage, is only the statistics. In the first half of August 2020. the number of all people infected with Covid around the world exceeded 20 million. The highest number of infections was detected in the USA - over 5 million, followed by Brazil (3 million), India (2.1 million), Russia $(880,000)$ and South Africa $(553,000)$. In Poland, from March to mid-August, approximately 53,000 infections were confirmed. By the end of the first decade of August 2020, 727,000 Covid-related deaths were reported around the world, again with the USA at the top of the list (162,000 deaths), followed by Brazil (100,000), and Mexico (52,000 deaths). In Poland, almost 1,900 people were reported to have died of Covid during that period.

The vast majority of countries around the world and their citizens were not sufficiently prepared for this global crisis. However, some of them were able to cope with the pandemic better than others. It would be difficult at this stage to indicate the reasons for such a discrepancy, as well as draw conclusions for the future. Nevertheless, it is definitely an issue that requires a careful examination.

Regarding the lack of sufficient preparation of individual states and their citizens for the "war" with the coronavirus, as well as the lack of sufficient knowledge about the causes of the difficulties experienced, so many factors come into play that it would be impossible to take them all into account. At this stage, too little is known about what exactly happened and how it happened, not to mention being able to identify the possible reasons for such a state of affairs. Certainly, what has to be analysed is both the impact of the virus and the crucial decisions made by various state, legal and other entities, as well as any acts or omissions on their part.

The above mentioned observations concern not only the situation at the beginning of the pandemic, when the lack of prior mental, material and organizational preparation for such a crisis became evident (Figure 4.), but also at its later stage. Without a minimum understanding regarding this subject, preparing for next challenges, opportunities and threats that the "civilization of risk" may bring (Beck, 2002; Beck, 2012), would be like "chasing a black cat in a dark room".

Some of the negative consequences of the lack of preparation became evident already 
in the first stage of the pandemic. This includes not only the dilemma experienced by doctors in many countries of who should be connected to ventilators (as the number of such devices in hospitals was often limited and insufficient), but also a shortage of such basic protective equipment as masks and face shields. The situation was aggravated by the fact that some people ignored the obligation to wear masks or maintain the required social distance. This resulted in a skyrocketing number of COVID-19 cases and related deaths, the most tragic examples of which, in the early stage of the pandemic in Europe, were Spain and Italy.

Over time, other dangers related to the pandemic and its consequences have come to light and this process is likely to continue for the following years. The mentioned dangers do not only concern the consequences of COVID-19 on people's health. In mid-2020, it was already evident that the pandemic would negatively affect many spheres of life, including economic, political, social, cultural, public, and perhaps even military security. However, are we talking only about negative consequences? The answer to this question and its practical implications may be of long-term strategic importance ${ }^{1}$. This raises yet another question : how should scientific research on this kind of meta crisis be organized and conducted, not only at the local and national level, but also on a wider scale? This article will hopefully be a useful contribution to such a challenging task.

The final part of the article presents conclusions for further research on mega-crises, their causes and effects, as well as methods of dealing with them. Some of these conclusions may prove useful for teaching in the field of safety, as well as other areas of study. The pandemic has highlighted weaknesses in certain legal regulations and organizational solutions, also in the widely understood national security system, and, in particular, in its subsystem of health safety. The situation is all the more difficult due to the fact that the concept of health safety has not been scientifically described so far, neither it appears in legal regulations. It is therefore hardly surprising that the activities undertaken in this area were not efficient and effective enough. This observation prompted the author of the article to make an attempt at a general characterization of such concepts as: health safety and health safety system/subsystem, but also health safety culture, as it cannot be ruled out that its current level did not allow for an effective fight with the coronavirus.

\section{Basic facts related to the main subject of the paper}

The following part of the article focuses on two stages of the pandemic: its outbreak

\footnotetext{
${ }^{1}$ This can be seen, for example, in the shortening of supply chains, often abnormally extended in the current, globalized world.
} 
(the first few (several) days), and the situation several months later, when - for both objective and subjective reasons ${ }^{2}$ - the restrictions imposed before started to be lifted or relaxed. which, however, resulted in a sharp increase in the number of infections and the related problems in various areas of safety. These were mainly related to inappropriate attitude of individuals, social and professional groups, which varied considerably depending on the country. In Poland, in the first few days and weeks of the pandemic, the majority of people behaved appropriately. This changed in the summer, after the previously imposed restrictions were relaxed. The examination of the causes of this situation could be an interesting research problem and a topic for a separate article. This paper, however, examines the dynamics of facts and pandemic-related problems changing over time and space. The model of the "alphabet of safety", developed for the needs of safety sciences, may be useful for that purpose. It is presented in Figure 1.

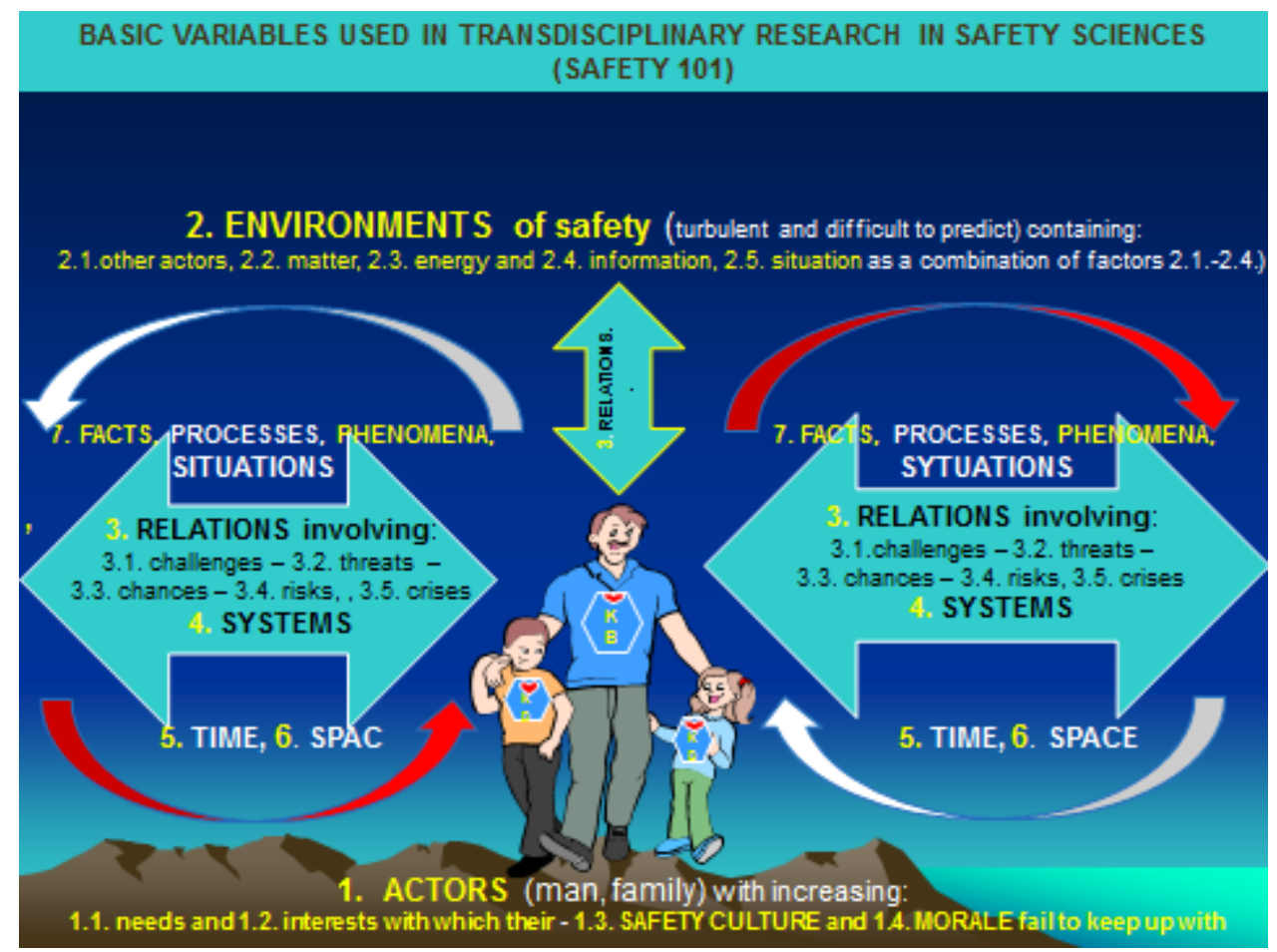

Figure 1. "The alphabet of safety" and its applicability during the pandemic Source: Own elaboration

The elements of this model, which combines knowledge from several scientific disciplines, will be referred to later in the article. The author applied it in order to interpret the events and processes that occurred in the first months of the COVID-19 pandemic in various countries around the world.

\footnotetext{
${ }^{2}$ Taking into account the needs of the economy, but also the human factor of psychophysical fatigue caused by limited movement of people and social groups, and imposed restrictions.
} 
The first coronavirus outbreak was detected in China in December 2019. Two months, the COVID-19 pandemic has already been spreading rapidly around the world, reaching Europe in March. In Italy, during just four days (March 21-24), the number of cases increased from 47,021 to over 60,000 , and the number of deaths - from 4,032 to over 6,800 . In Lombardy alone, more than 400 infected people died in one day. At the end of the month, according to official announcements around 1,000 people were dying of Covid in a day in Italy. In Spain, in the same period, the number of COVID-19 cases increased from 21,571 to 39,700 people, and the number of deaths from 1,093 to 2,696. The statistics from France and Germany show a similar trend. In France, at that time, the number of COVID-19 cases increased from 12,612 to 22,000 , and the number of deaths from 562 to 1,100 , while in Germany, the number of infected people rose from 19,848 to around 35,000, and the number of related deaths from 68 to $206^{3}$.

What became clear at that time was that the ability to manage time and space (see: Figure 1.), as well as the associated risks, should not be underestimated. Different cultures attach different level of importance to this kind of competence of individuals and legal entities. In Poland, people have only started to learn it. It is, however, an important element of the organizational and safety culture. In addition to the ability to manage time and space, significant differences across countries were also observed in terms of individual and institutional decisions, behaviour, actions and cooperation between individuals and legal entities.

Here, it is worth to go back to the situation in Italy and its underlying causes ${ }^{4}$. According to Dr Piotr Podemski, an Italianist at the University of Warsaw, from the very beginning of the COVID-19 outbreak in Italy, a long series of mistakes was made that contributed to the rapid spread of the disease. The country's first COVID-19 case was officially confirmed on February 20 in the town of Codogno, Lombardy. According to the researcher, the doctors in Codogno had long been pondering on a puzzling increase in the number of strange, persistent pneumonia cases in that area, against which regular medication was not effective. The number of patients grew. Some of them died, but these were mostly elderly people. Thus, the infections and the related deaths were explained by the old age of

\footnotetext{
${ }^{3}$ Due to the high dynamics of changes, the data used should be considered as approximate. During analysis, it is also worth remembering that the dates when the first infections were detected, as well as the rate, in which the disease was spreading, varied across countries.

${ }^{4}$ Part of the data presented in this part of the article was also included in the paper Citizens' safety culture in selected EU regions and ways of dealing with the covid-19 pandemic, intended for presentation during a scientific conference organized by IBIMA (Spain) in the first half of 2020.
} 
the patients, who often had other coexisting diseases. The infected people were not isolated, so the disease spread all over northern Italy. Over time, when the situation began to grow more serious, the country began to introduce closed or restricted zones. However, the restrictions were not effective enough, and the coronavirus continued to take its toll. Among those who died of coronavirus in Italy, there were twice as many men as women, as indicated by a report of the national institute of health.

The situation in hospitals in Lombardy was becoming more and more desperate, especially in intensive care and resuscitation units. This was reported by doctors and local authorities in the media. "It is a tsunami - hospitals are full, we are running out of places for patients in the region" - told the media a doctor named as Riva. He went on to explain: "In intensive care units, we intubate seven people or more in a single day and work without a break, with a day off every 14 days or so". "We will soon reach a point when we will no longer be able to resuscitate people because we will be out of intensive care unit beds," warned Attilio Fontana, governor of Lombardy, in an interview with the Sky TG24 network. He also informed that one of the more serious problems for the local health care was the lack of a sufficient number of ventilators. Efforts were being made to create additional space for patients in hospitals. "Patients die all alone, they are begging to say goodbye to their children and grandchildren" - said in an interview Dr Francesca Cortellaro. This sparked off an idea to place tablets in intensive care units so that dying patients could say goodbye to their loved ones.

Meanwhile, the Mayor of Bari in Puglia (southern Italy), Antono Decaro took it upon himself to rebuke citizens who would not respect the stay-at-home rule. "This is a national crisis, not a game. The images and recordings from Milan or Bergamo are not a movie, they are real, people are dying there" - cried out Decaro, walking around the city. It is worth to point out that the behaviour of people in many other European countries, as shown in the media, was similar to the situation in Italy. Among those who died in Italy from the coronavirus at that time, there were twice as many men as women. Research carried out in Poland in 2011 showed a higher level of safety culture for women than for men ${ }^{5}$. It cannot be ruled out that during a crisis, when there is a lack of information and knowledge, women are

\footnotetext{
${ }^{5}$ Filipek A., Research report on Safety culture of entities as an element integrating the national security system and regulating its functioning and development (Kultura bezpieczeństwa podmiotów jako element integrujacy system bezpieczeństwa narodowego oraz regulujacy jego funkcjonowanie i rozwój), as part of the Project: National Security System of the Republic of Poland (System Bezpieczeństwa Narodowego RP), which is a project in the field of national defence and security financed by the National Centre for Research and Development Agreement No. DOBR/0076/R/ID1/2012/03 of 18.12.2012, project registration number: O ROB/0076/03/001, AON, Warsaw 2013.
} 
able to act on intuition better than men (Jessel, Moir, 2014).

In the third decade of March, new outbreaks of coronavirus were reported in Italy. "There are still too many infections and the situation in the north of Italy is catastrophic". This is how another day of the ongoing pandemic in the country was summed up by Giovanni Rezza - head of the infectious diseases department at the National Institute of Health. He stressed that every measure should be taken in order to ensure that the pandemic-related restrictions are followed throughout the country. as, in his opinion, the level of compliance was far from sufficient. Commenting on the growing number of infections among medical personnel, the representative of the Institute of Health emphasised: "this is a serious problem, which emerged due to the fact that our approach to safety was not serious and rigorous enough. It is also true that our medical staff ran out of PPE and that our European neighbours were not helpful in this regard. The current statistics related to coronavirus in Italy indicate 3,405 deaths - more than in China - and over 41,000 confirmed cases of infection". However, he did not take into account the fact that almost every country in Europe had already been experiencing the consequences of the pandemic at that time, not only in the area of health safety. The impact of the pandemic on the economy was also evident just a few months after its outbreak.

Specialists from the consulting firm Kearney, in a report Responsible actions of managers in the COVID-19 era wrote that “(...) the industries that are particularly vulnerable to the pandemic-related challenges are those that are based on the movement of people and services, as well as those that, at the moment when a new global threat appeared, were already struggling. Other industries will not experience such a strong negative impact of the pandemic on their business activities." However, according to the authors of the report, the global scope of the pandemic and the imposed restrictions have led to an imbalance in world trade and have severely impacted supply chains. Also, the actual scale of the crisis remains unknown.

Experts from various industries comment on the seriousness of the situation. "COVID19 clearly takes its toll on supply chains, starting with industrial production, which has experienced a drastic slump (especially in China, which is regarded as the "factory of the world'). The difficulties are caused by shortages in staff and PPE required for work, as well as the forced quarantine of workers suspected to have COVID-19. In addition, restrictions on movement have caused a sharp drop in demand (and thus prices) for land and air transport, causing the paralysis of these sectors of economy" - said Jakub Dudzic, a Kearney consultant.

Kearney's report indicates that the key to ensuring business continuity is effective support for remote work of employees. What is helpful in this regard is technology, which 
provides numerous tools and channels of communication. "We have clients who have shifted most of their office staff to remote work almost overnight and without any loss of efficiency. On the other hand, there are also those who prefer to minimize remote work, regarding it as something unusual for their organization. The same applies to customer relations. Those companies that have invested in multi-channel operation and are selling their products and services both in stationary points as well as through mobile applications and online stores, have been relatively less affected by this extraordinary situation caused by the pandemic" observed Krystian Kamyk, Kearney Director.

For some time, panic on stock exchange grew as the number of coronavirus cases skyrocketed. In Europe, the infection rate was at its highest at that time, while in the USA it began to accelerate. The decisions made by the Federal Reserve System, instead of improving the situation, only added fuel to the fire in terms of growing fears on the market. The Wall Street stock exchange was halted for 15 minutes right after the opening of the session. This was already the third such case in the last six days. The reason was the decline in the S\&P500 index by $8 \%$, which automatically triggered suspension of the session to calm down the investors. Within just a few minutes, the stock market value of S\&P500 companies fell by $\$ 2$ trillion, calculated Reuters. The above-mentioned decision made by the FED to cut interest rates to zero, instead of stimulating the market, stimulated a panic mood. "The fear factor is going through the roof this morning"- commented Peter Cardillo, chief market economist at Spartan Capital Securities in New York, for Reuters. "Markets are spooked by the emergency of the central banks stepping in and adding billions of dollars of liquidity" - he added. Traders also fear that closing the traffic between countries will cause a paralysis of supply networks around the world, which will hit hard corporate finances. Therefore, the decision on interest rates is regarded as a confirmation that the financial world is in serious trouble. Apple, Amazon and Microsoft have reportedly lost a total of around $\$ 300$ billion in market value.

The coronavirus reached Poland somewhat later than other countries, allowing for better assessment of the situation and taking more rational actions. This does not mean, however, that our country has completely avoided mistakes. On April 8, by 7 p.m., there were 4,948 people infected, and 159 deaths. In the evening on April 14, 7202 infections were reported in total and the number of deaths rose to 263. Three days later, on April 17, by the evening, there were already 8379 people infected and 332 deaths from the coronavirus. It was believed then that the peak of infections in Poland was yet to come. Another sudden attack of this invisible "enemy" took place in the first half of August 2020, when, under social and economic pressures, many previously imposed restrictions were lifted. While they were soon 
reimposed at a local level ${ }^{6}$, it was not easy force people back into the mostly disciplined and responsible behaviour from the onset of the pandemic. Even fines did not seem to bring the expected results. This resulted in about 55,000 COVID-19 infections and almost 1,900 coronavirus-related deaths reported in the second decade of August 2020. Hospital directors warned that if the infection rate keeps rising, specialist hospitals may soon run out of beds ${ }^{7}$.

Compared to other European countries, in the first months of the pandemic, Poland was dealing relatively well with the problems emerging in the health sector, as well as other areas. Also, as has been mentioned before, the citizens' attitudes at the beginning of the pandemic were relatively responsible, at least in the vast majority of cases. This began to change after a few months. Identifying the causes of this shift of attitude can be an important challenge for researchers of safety issues ${ }^{8}$. As indicated before, the insufficient level of safety culture of citizens, confirmed a few years ago by empirical research, might have contributed to this phenomenon (Filipek, 2013; Cieślarczyk, 2015). It is worth to note that the concept of safety culture was mostly disregarded in academic curricula, despite the fact that the phenomenon has been studied in our country for twenty years ${ }^{9}$. These studies so far can be regarded as individual cases, but it cannot be ruled out that the experiences with the pandemic will draw more attention to the existence of the phenomenon of safety culture, promote further research on the subject and use its results to raise the level of safety in the next decades of the 21 st century. Although, as the saying goes one swallow does not make a spring, it is worth to point out that in 2019 the Safety Culture Foundation was established in

\footnotetext{
${ }^{6}$ The decision to introduce various restrictions in individual districts, depending on the number of infections, was by all means correct, not only for health and economic reasons, but also as a socio-organizational mechanism for introducing discipline and building a sense of responsibility for the common good among citizens.

${ }^{7}$ In discussions about the impact of the pandemic on various aspects of life and safety, there have hardly been any mentions of its impact on the ability to treat patients with other diseases.

${ }^{8}$ Perhaps it was mainly based on one segment of the safety culture, which is the culture of fear, shaped by the oppressor during the period of Partitions and passed down to next generations. This one of the possible hypotheses. Although the culture of safety has been changing to a different extent in different regions of our country over the last quarter of a century, it is worth to remember that the changes related to mental aspects and awareness (see sphere A in Figure 4.) occur relatively slowly, especially when particular segments of awareness are not shaped by the media and teachers.

${ }^{9}$ The concept of safety culture began to be used more widely in the scientific world after the disaster of the Chernobyl nuclear reactor in the former Soviet Union. Nevertheless, a few years later, the interest in this subject had waned. In a similar way, after the tragic events of September 11 and the disaster at the Fukushima nuclear power plant, the term started to appear in scientific publications and attract interest, only to be forgotten again. It cannot be ruled out that the difficulties with the dissemination of knowledge about the safety culture and its practical use are related to the complexity of this phenomenon and its abstract nature. In Poland, the issue of the culture of safety started to be systematically studied about twenty years ago. See: M. Cieślarczyk, Spoleczeństwa
} 
Poland. Also the Office of Rail Transport is actively involved in promoting the safety culture in the railway transport sector ${ }^{10}$.

As a conclusion of this part of the article, it can be said that in the second half of 2020 a significant loss of morale of the majority of Polish society in the fight against the coronavirus was observed (Cieślarczyk \& Kołodziejczyk, 2019). ${ }^{11}$ This can possibly indicate that the positive changes in the culture of safety, which have been taking place in Poland since the 1990s, have not yet been consolidated enough to play the role of a "shield and sword" in the long-time perspective, or a "lifeline" to be taken advantage of in crisis situations (Filipek, 2013; Cieślarczyk, 2015). ${ }^{12}$. This is not surprising, as - apart from two academic centres in our country (the Military University of Technology in Warsaw and the University of Natural Sciences and Humanities in Siedlce) - the issue of safety culture in the teaching process has practically been disregarded, despite the fact that the correlation between safety culture and the morale of people and legal entities has been scientifically described (Cieślarczyk \& Kołodziejczyk, 2019).

The problem mentioned above raises the question of how to examine the difficulties and phenomena in the area of the broadly understood safety that occur during the COVID-19 pandemic, as well as how to use the implications of such research in practice At attempt to answer these questions will be made later in the article. Particular attention will be paid to the issues of health safety and the culture of health safety, the author's understanding of which will be presented at the end of the article. It is likely that the lack of these concepts in the scientific literature on the subject, as well as in formal regulations - not only in Poland - has contributed to the fact that the actions undertaken in various countries to fight the pandemic could hardly be called systemic and effective.

i społeczności na przełomie wieków - od bezpieczeństwa kultury do kultury bezpieczeństwa. Referat na Ogólnopolskim Zjeździe Socjologicznym w Rzeszowie, 2000 i inni.

${ }^{10}$ In the summer of 2020, the Dean of the Faculty of Security, Logistics and Management, on behalf of the Rector of the Military University of Technology, signed a cooperation agreement with the Office of Rail Transport for the promotion of the safety culture.

11 Research shows that the phenomena of morale and safety culture can be described using an analogy of communicating vessels. This means that by improving the safety culture of individuals and legal entities, we contribute to strengthening the morale of these entities. The current didactic experience allows for a conclusion that the safety culture can be diagnosed and improved.

12 The nationwide empirical research carried out in 2013 showed that the safety culture of inhabitants of certain districts in Poland was not - to put it mildly - to o impressive. Only state services stood out in this regard compared to local government units and ordinary citizens. The upcoming months will show to what extent people have adopted it. 


\section{In search of knowledge for a better understanding of events, processes and phenomena during the COVID-19 pandemic}

Over time, the COVID-19 pandemic may start to be treated as one of the most important challenges of the past few decades (Cieślarczyk, 2006, pp. 119-120) ${ }^{13}$. However, it is worth to remember that challenges may pose not only threats, but also opportunities. Some of them are discussed later in this paper.

An attempt is also made to answer the question of what elements of knowledge in the field of safety sciences can be most useful for describing and explaining various processes and phenomena that occur during a pandemic, which is an elaboration of the previously formulated question. While searching for the answers, observations and experiences, both the positive and negative ones, gained during the pandemic were used, as well as the empirical research conducted several years ago and the available scientific literature on the subject. However, the sheer variety of unprecedented events and phenomena that emerged during the pandemic in various countries did not facilitate this task. Such information turbulence, not only at the beginning of the pandemic, but also later, made it difficult to collect reliable data. Therefore, it was necessary to find a method of collecting and "screening" the most important information in the "ocean" of data of varying reliability, as well as to develop a method of processing the selected data in order to obtain relatively reliable and comprehensive answers to the questions posed herein.

It was not an easy task due to the complexity of the research topic and the large amount of, often contradictory data on the subject, mentioned earlier. For these reasons, this article has a greater theoretical and methodological value than empirical one. Nevertheless, in the process of its compilation, the author was describing specific events, processes and phenomena of varying intensity in individual countries in Europe and around the world during the COVID-19 pandemic. The available data was collected and processed in a holistic way

\footnotetext{
13 A challenge is understood as a new situation, important from the point of view of a given entity, or information about such a situation. If a given situation is properly read and interpreted by an individual or a legal entity, it may turn into an opportunity if it happens at the right place and time. Otherwise, the challenge may become a threat. Proper perception and reception of a challenge is only one of the requirements for it to turn into an opportunity. During the identification and interpretation of the challenge, appropriate individual and joint actions should also be taken 9 appropriate in the sense of "adequate to the needs", but also happening in the right place, at the right time, in the right way). A challenge may become a threat when it has not been identified or/and misread, but also when actions were not taken as a response to that challenge, were taken too late or were inadequate to the needs. The current experiences with the pandemic provide many examples to corroborate the validity of such an understanding of the term "challenge".
} 
(Figure 2.), using an inter- and transdisciplinary research approach ${ }^{14}$.

It has already been mentioned that such a complex crisis as the COVID-19 pandemic, considering the cascading challenges, threats, opportunities and risks that it brings, as well as the rapidly changing relationship between entities and their environment (see Figure 1), is problematic from the point of view of studies on safety issues. This mega-crisis that the world is currently trying to deal with has manifold causes and multidimensional consequences that should be analysed at different time intervals.

It should be stressed that when trying to describe and explain events, processes and phenomena occurring during a pandemic, knowledge from a single discipline, or even a field of science, may be insufficient. For this reason, the inter- and transdisciplinary approach may prove useful or even indispensable. Insight gained with the use of such an approach should, on the one hand, be used to solve the cascading problems and, on the other, be used to supplement the safety science and its subdiscipline - the culture of safety (Wróblewski, 2019, pp. 342-345).

In the article, the author presents several models that have been adopted in safety sciences, which proved to be useful in research on multi-faceted problems created by the situation related to COVID-19. One of these models is presented in Figure 1. The first part of the research mentioned some of the problems that have emerged during the pandemic in various countries around the world through the perspective of the "alphabet of safety" and its elements. However, this was only an initial, and somewhat intuitive, opportunity to use this synthesized knowledge in order to better understand complex events, processes and phenomena that have emerged and will continue to emerge during the pandemic like the iceberg on Titanic's route.

However, in order to design and implement more complex research on safety problems occurring during the COVID-19 pandemic, it is worth to use another model, which is presented in Figure 2. Although its first draft was developed in the last decade of the 20th century (Cieślarczyk, 1997, p. 110), it was mostly disregarded in the first years of the 21 st century, as for quite a long time there were no opportunities to use it in scientific research. Neither did it attract the attention of lawmakers, who were developing not always consistent

\footnotetext{
${ }^{14}$ In can be simplified that interdisciplinary research involves "merging", multidisciplinary research "combining", pluridisciplinary research - "distillation", while transdisciplinary research - "arbitrary assembly", which resembles playing with Lego blocks. In addition to knowledge, intuition and imagination is also useful, as well as a holistic and systemic perception of reality and the related ways of thinking and acting. To be more specific, it can be said that the starting point for multidisciplinary research should be a holistic safety model.
} 
legislation with regard to the National Security System and its subsystems ${ }^{15}$. This also applies to health safety systems, as many countries may have learned the hard way during the pandemic, or even much earlier. It is worth noting that the applicability of this model - similar to several others presented later in the article - was tested empirically a few years ago in a nationwide scientific research on the crisis management subsystem (Filipek, 2013; Cieślarczyk, 2015). The limited scope of this article does not allow for a detailed description of all these models, hence, only selected ones have been taken into account.

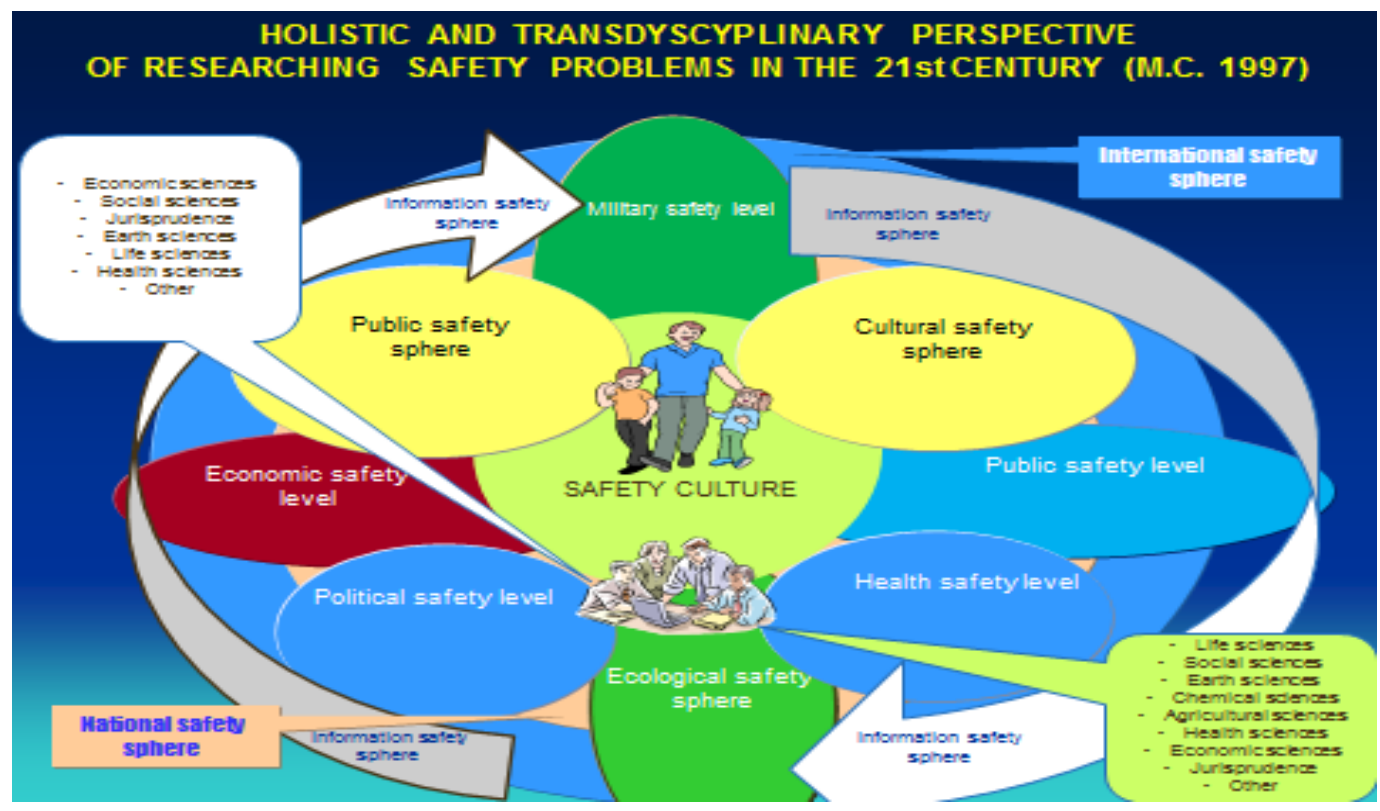

Figure. 2. Applicability of the holistic perspective and the transdisciplinary approach in researching safety problems during and after the pandemic

Source: Own elaboration

It is worth paying attention to the fact that in the above-mentioned models the culture of safety plays a critical role ${ }^{16}$. The existing research shows that in the face of increasing complexity of the modern world and legal regulations, the culture of safety may play a strategically important role as an internal (in the subjective sense) regulator of various forms

\footnotetext{
${ }^{15}$ See: Reports on research under the Project: System Bezpieczeństwa Narodowego RP (National Security System of the Republic of Poland, project in the field of national defence and security financed by the National Centre for Research and Development) - agreement no. DOBR/0076/R/ID1/2012/03 of 18.12.2012, project registration number: O ROB/0076/03/001, AON, Warsaw 2013. This was probably due to the fact that there had been no previous experience similar to the Covid-19 pandemic.

${ }^{16}$ It has already been mentioned that this phenomenon started to attract interest after the Chernobyl disaster, but after several years that interest had faded, mainly due to its multidisciplinary complexity. Currently, only two research centres in Poland (the Military University of Technology in Warsaw and the University of Natural Sciences and Humanities in Siedlce) examine this phenomenon and its use in the academic teaching process. In recent years, the staff of the Main School of Fire Service have also become interested in the culture of safety, as well as the Office of Rail Transport, which is focusing on its practical application.
} 
of activities of people and institutions ${ }^{17}$. An appropriate level of safety culture of these entities may also contribute to the achievement of sustainable development in the personal (Figure 3.) and structural (Figure 4.) dimensions. The ideal model of this concept is presented in Figure 2. and Figure 3.

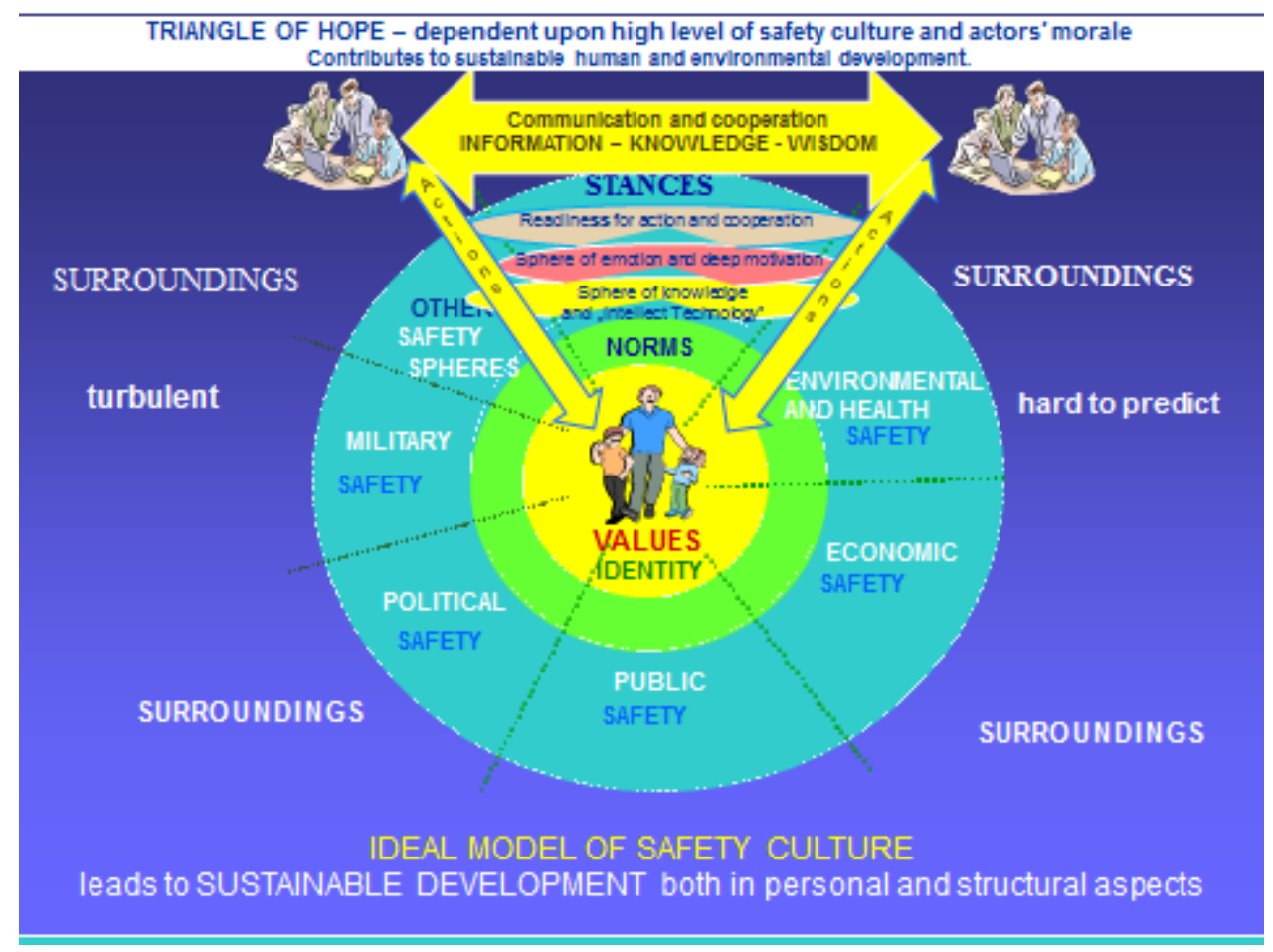

Figure 3. An ideal model of safety culture Source: Own elaboration

However, the practical aspects of the functioning of individuals and legal entities differ from the theory, which came to be evident during the pandemic. Therefore, the phenomenon of safety culture, as an important element of the defence potential (Cieślarczyk, 2006, pp. $235-254)^{18}$, is analysed in the further part of the article, along with new models showing different "faces" of safety culture. For further considerations, two complementary models of safety culture seem particularly useful: the psychosocial model, shown in Figure 3., and the structural and organizational model, presented in Figure 4. Both earlier research on the importance of safety culture in crisis situations ${ }^{19}$, as well as observation of the behaviour, actions and cooperation of individuals and legal entities during the COVID-19 pandemic

\footnotetext{
${ }^{17}$ One of the first state institutions in Poland to become interested in the safety culture and implement the academic achievements in this field in practice was the Office of Rail Transport, with which the Dean of the Faculty of Safety, Logistics and Management has recently signed a cooperation agreement.

${ }^{18}$ Defence is understood in its broad sense, not only in terms of military aspects.

${ }^{19}$ For the needs of the crisis management system, such research was carried out in 2013 for the National Security Bureau as part of the project National Security Strategy of the Republic of Poland. The results of this research are available in: (Filipek, 2013; Cieślarczyk, 2015).
} 
indicate that at such a time the safety culture plays the role of an all-purpose type of competence and a "lifeline", enabling individuals and legal entities not only to survive, but also to enter the path of development.

\section{ENVIRONMENT}

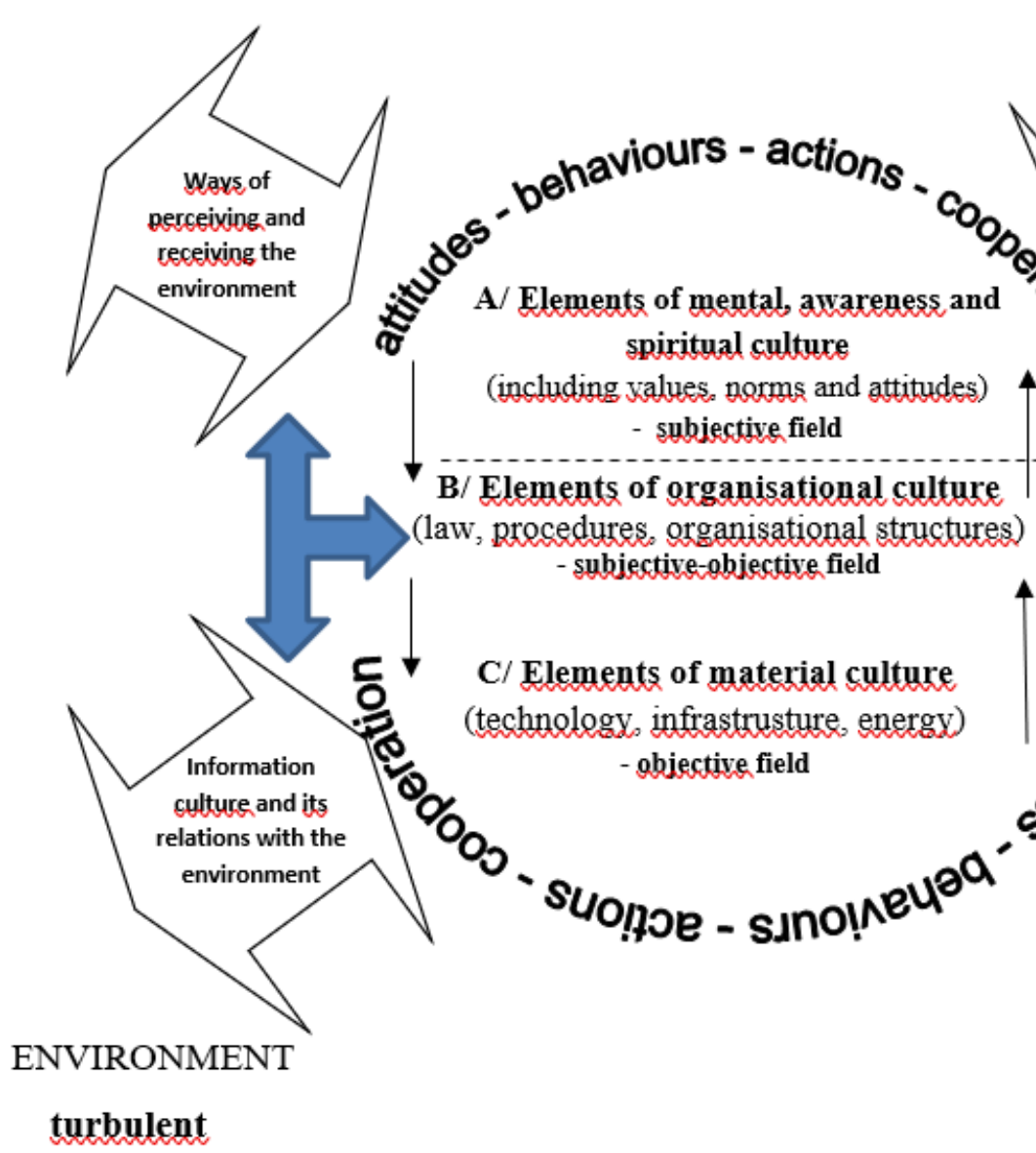

\section{ENVIRONMENT}

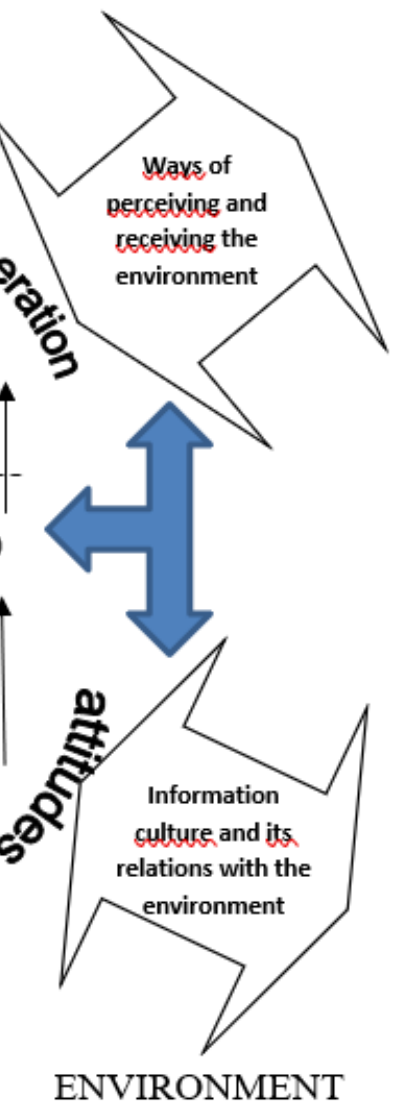

hard to predict

Figure 4. Structural elements of the safety culture and their applicability in describing the requirements for effective fight against the COVID-19 pandemic.

Source: Own elaboration.

This can only happen when two requirements are met. First of all, these entities must have a sufficiently high level of safety culture and morale ${ }^{20}$; secondly, the differences in the level of safety culture of individual social and professional groups must not be too large ${ }^{21}$. In

\footnotetext{
${ }^{20}$ Research shows that the safety culture and morale can be described using the analogy of connected vessels. This means that by improving the level and nature of the safety culture of individuals and legal entities, the level of their morale can also be raised. Arguments supporting this thesis can be found in: (Cieślarczyk \& Kołodziejczyk, 2019). It is likely that this fact may be of considerable importance in the "war" against the coronavirus.

${ }^{21}$ Research shows that the level of safety culture of local government administration units is relatively low and close to the level of the majority of citizens. In contrast, state services that are part of the crisis management system are characterized by a much higher level of safety culture. See: (Cieślarczyk, 2015).
} 
turn, when its level is insufficient and its nature dysfunctional, it may become the proverbial "ball and chain" for a given individual or legal entity.

It has already been mentioned that the nature of the subject of research, which is the COVID-19 pandemic, as well as its scope and the number and complexity of problems it generates in various spheres of life and safety of people, social and professional groups, countries, societies and communities, such as the EU, forces to use theoretical knowledge at an optimal level of generality, and adapt it to the research needs. The author adopts this assumption in order to address the issues that are likely to attract more attention in the years to come than ever before. What is meant here is a broader understanding of such concepts as health, health safety, health safety culture and the health safety system/subsystem.

\section{Characteristics of a broader perspective on health and safety ${ }^{22}$}

A broader way of thinking about safety and health was not often adopted in the scientific discourse before the pandemic. Neither was it taken into account in formal regulations or the practical functioning of safety systems (including the health system). In contrast to the narrow understanding of these two concepts, in this case the changes in some sphere of life and safety are not assessed solely in terms of threats occurring in a single sector of safety (Figure 2. and Figure 3.). Such threats are rather considered as a challenge, which may bring both opportunities and risks for several areas of safety. The pandemic has shown that the current mega-crisis, which originated in the health safety sector, spread over time to other spheres of safety (Figure 1. and Figure 3.). By the second half of 2020, its consequences for the areas of economic and political safety (as well as many others) were evident. This raises the (probably rhetorical) question of whether societies and institutions were thinking about safety and health, as well as health safety, in the broad sense of these concepts before the pandemic, or not necessarily.

Scientific considerations about health and safety in their broad sense also include development as a requirement for their long-term implementation. One can, therefore, venture an observation that the underestimation of the category of development ${ }^{23}$ by individuals and

\footnotetext{
${ }^{22}$ Fragments of this text have been submitted by the author for a publication prepared by employees of the Department of Security, Logistics and Management of the Military University of Technology, entitled The Influence of COVID 19 Pandemic Crisis on regional and national security in military, economic and managerial issues.

${ }^{23}$ Later in the article, two concepts within the category shall be distinguished; although in the common understanding they are used interchangeably, development and growth shall be defined as follows: if something (someone) develops, it means that it becomes more perfect; if, in turn, one is talking about growth, it shall mean something (someone) becomes bigger in size.
} 
legal entities could have contributed to the negligence in terms of anticipating and preventing the consequences of COVID-19, as well as various threats and crises it generated in many spheres of life and safety, at the beginning of the pandemic. For this reason, the response to the outbreak of the coronavirus in many countries was slow and inefficient, as previously mentioned.

This problem was also evident several months after the outbreak of the pandemic, when decisions were made about the relaxation of the previously imposed regulations. mostly due to economic and psychological reasons, but also due to the negative impact of the pandemic on other spheres of life and safety at the local, national or transnational level (e.g. within the EU). Only then it became clear that too little attention had been paid to the relationship between the concepts of health and safety in theoretical, formal, legal and practical terms (Figure 4.). Both the deficit of knowledge on this subject, as well as the lack of appropriate formal regulations and experience in this regard contributed to the fact that both the decisions of the authorities at various levels and the behaviour of citizens were often far from optimal, which showed the actual level of safety culture of individuals and legal entities. Therefore, in the face of a multitude of various variables, while looking for a meta factor that could be useful both in theory and in practice, as a kind of "interface" connecting various spheres of life and safety of individuals and legal entities, attention was drawn to the culture of safety (Figure 2.). Its importance in practical terms is related to the fact that it is "rooted" in one of the basic human needs and values - safety (Figure 4.). When safety, just like health, is understood in a broad way, it contributes to shaping a higher level of safety culture, which becomes, as it were, a "lifeline" for individuals and legal entities. Otherwise, a low level of safety culture among citizens may resemble the proverbial "ball and chain". In some countries it was evident not only at onset beginning of the pandemic, but also - as already mentioned several months after its outbreak, when, for psychological and economic reasons, attempts were made to relax the previously imposed restrictions. Then it became clear that for psychological and political reasons it would be difficult to return to the previous regulations, and the spread of the virus puts individuals and legal entities in a "vicious circle". Overcoming it and entering the path of development would entail many dilemmas, with human life and large economic losses at stake. This situation was particularly dangerous for entities with a low level of safety culture. It turned out to be dangerous not only for those infected, but also for their immediate surroundings.

It is also worth to make an observation here that both analysed phenomena - safety and health - are similar also in terms of their functions. The broadly understood safety and health are to 
ensure "survival" for individuals and legal entities under normal conditions, by ensuring an adequate quality of life, as well as in crisis situations. However, it is hardly remembered that both in everyday life and during crises, care for health and safety should be manifested in striving for "development" (ideally - sustainable development) in the personal and structural dimension ${ }^{24}$. What may be helpful in this regard is a holistic approach to health and safety ${ }^{25}$. The need for a holistic approach to safety and health (illustrated in Figure 2) was indicated in Polish literature on the subject in the middle of the last decade of the 20th century. The model of a holistic approach to health takes into account the following dimensions:

a) physical (biological functioning of the body);

b) mental (cognitive and emotional functioning of the body);

c) social (the ability to maintain good interpersonal relations);

d) spiritual (personal beliefs and religious practices, but also an appropriate level of morale).

Until recently, however, it has mainly been a theoretical model. Due to the lack of preparation of individuals and institutions, the "attack" of the coronavirus has had a devastating effect on all four of the above-mentioned aspects of the broadly understood public health. It has also disturbed the state of dynamic equilibrium between the aspects indicated above and the state of illness, understood in the clinical sense. What turned out to be especially problematic was that the outbreak of the coronavirus was random, and the nature of the information security culture as well as specific interests of individuals and legal entities did not facilitate the early identification of threats and efficient pre-emptive actions. There were also difficulties related to assessment of the situation ${ }^{26}$ and risk management in terms of various spheres of life and safety of individuals and legal entities. It would be easier for institutions and organizations to deal with this problem if citizens were better prepared to minimize the risks within their competences. This, however, was not the case. Hence, the so-called "manual control" only managed to temporarily limit the spread of the virus, whereas health safety "systems" were "systems" in name only.

\footnotetext{
${ }^{24}$ It must not be forgotten that during the economic crisis in the first decade of the 21 st century, economists became more aware of the level of their ignorance, just as representatives of medical sciences and the health care system did during the COVID 19 pandemic. There is an opinion that both of these professional groups should seek new paradigms necessary for more effective methods of dealing with new challenges and threats to civilization. This, however, requires a change in the way of thinking about health and safety, and the related ways of organization, operation and interaction in the interpersonal and inter-institutional dimension.

${ }^{25}$ This is important as the perception, understanding and definition of the categories of "health" and "illness" reflect the adopted way of seeing reality, which determines the foundations for systemic solutions for health care and affects planning of the budget for the health care system (see: Piontek \& Macha, 2016).
} 


\section{Health safety, health safety system and health safety culture}

As early as two decades ago, researchers dealing with the issues of safety, were already pointing out that the existing understanding of the concepts of health and safety is too narrow and insufficient (often dysfunctional) in relation to civilization changes, both the positive and the negative ones.

Too narrow understanding and use of these concepts in academic research, academic teaching process as well as in social awareness was also reflected in formal regulations, organizational structures and in the functioning of individuals and legal entities, which became most evident during the COVID-19 pandemic $^{27}$. The pandemic has shown that the narrow understanding of these concepts has become ineffective in the face of new challenges and threats, but also new opportunities and risks. The problems encountered during the pandemic by individuals and legal entities, including states and societies, as well as institutions and organizations, forced to reconsider the way of thinking about health and safety, as well as searching for new ways of ensuring health safety. Although the term health safety was introduced years $\mathrm{ago}^{28}$, its dissemination took time. The pandemic is likely to accelerate this process. In the light of the current experience with the COVID-19 pandemic experience, it is worth to make an attempt to define health safety, using the knowledge related to the broadly understood concepts of health and safety.

At this stage of research, it is suggested to understand health and health safety as both a need and a value. It is a type of resource and common good shared by individuals, families, business and legal entities, local communities, societies, and our species as a whole. As the colonization of space begins, such a way of thinking about health and health safety is likely to become widespread, and the nature and importance of the health safety culture will evolve along with it.

The pandemic has also shown that health safety is both a state and a process that characterizes individuals, social groups, communities and societies. It is manifested by reducing threats to the health and life of citizens to a socially acceptable level of risk. An appropriate level of health safety should enable individuals and legal entities to survive and develop - preferably in a sustainable way - in several dimensions: physiological, psychosocial, intellectual and spiritual. This, in turn, would allow to achieve an optimal quality of life and

\footnotetext{
${ }^{26}$ This type of competence is developed only in certain universities in highly developed countries.

${ }^{27}$ In some countries, physicians had to face the dilemma which patients they should connect to ventilators and which they should leave to die, as the number of these devices was insufficient for their needs.
} 
development in the above-mentioned aspects, depending on objective, subjective and organizational (Figure 4.), as well as social and cultural conditions (Figure 2. and Figure 3.).

Health safety, combined with information security, is the basis for development of other types of safety, such as: economic and political, social and cultural, as well as public and military.

The level of health safety depends, on the one hand, on the condition of individuals and social groups, and on its changes due to various forms of activities of individuals and legal entities (or the lack of such activities or disproportions between them in various areas). On the other hand, the level of health safety depends on the quality of the different types of environment, in which this activity is undertaken, including natural and social, economic and cultural, as well as technical and information environment, as well as systems of knowledge and wisdom.

Maintaining a relative harmony between all these environments is a prerequisite for long-lasting health safety. The culture of health safety of individuals and legal entities can also be useful to achieve that purpose. It is worth to emphasise that citizens and their level of health safety culture are an important, though not always appreciated element of the broadly understood health safety system. The COVID-19 pandemic has provided enough evidence to support that view.

Such a way of thinking about health safety is close to the broadly understood health safety system, which includes the following subsystems: a/ health promotion and development, b/ health protection, c/ emergency medical services and d/ other. In Figure 1, the above-mentioned (sub)systems are marked with number 4 . The figure also illustrates other elements included in the broadly understood health safety system.

Health safety culture, just as health and safety, can be understood in its narrow or broad sense. In the simplest, narrow sense, it can be treated as a way of thinking about health, a way of feeling and experiencing health, as well as a way of guaranteeing it. The differences between people and socio-professional groups with such an understanding of the culture of health safety, as compared to people who had adopted a broader understanding of this concept, could be easily noticed during the pandemic.

In a broader sense, the elements of the culture of health safety include the scope and nature of knowledge about health, its preservation and improvement, possessed by individuals and legal entities, as well as the ability to use this knowledge for health promotion,

\footnotetext{
${ }^{28}$ See: (Wysocki \& Cianciara, 2016; Cieślarczyk, Filipek, Świderski \& Ważniewska, 2016; Cieślarczyk, Trzpil \& Zbroszczyk, 2016).
} 
improvement and development. What plays an important role is the way of thinking about health, including health-related challenges, opportunities, threats and risks. The pandemic has shown the importance of the way of experiencing health safety and reacting to emerging threats.

The key element of the health safety culture are the rules and principles adopted by people, as well as values and norms that guide them in various situations affecting their health. Depending on the level of safety culture, either the health of other entities is also taken into account, or it is disregarded. Compliance with the above-mentioned principles affects the way of acting and interacting with other entities, with one's own safety, as well as the safety of other individuals and legal entities in mind. Entities with a higher level of safety culture are thinking not only in terms of "here and now", but also in terms of "somewhere and later".

The elements and aspects of the health safety culture, its structure and functioning can be better understood using the Figures 1-4 presented earlier, especially Figure 3. In the upper part of this figure, one can see the place and role of information systems for ensuring the safety of entities, as well as the information and communication culture. The level of information and communication culture is a universal type of competence, the importance of which will grow in the coming decades of the 21 st century - the century of information, knowledge and wisdom. The shortcomings of the information and communication culture was particularly evident during the pandemic. If these universal competences are not acquired by individuals and legal entities, the successful implementation of the already launched mission to colonize space will prove difficult in the near future. It can be said with a relatively high degree of certainty that the opening of the mega-system and the venture of humankind into space is a condition for the survival and development of the Homo Sapiens species. In carrying out this mission, the importance of the broadly understood health and safety culture will increase.

\section{Conclusions}

The current experience with the COVID-19 pandemic shows the need for a broader, holistic way of dealing with health and safety issues in various areas. This will make it possible to examine the relationship between different areas of safety. Knowledge in this regard should be used in education systems, for improvement of the legal system and ensuring safety in practical terms. Insight gained during the pandemic can be useful for redefining and improvement of safety systems, as well as adaptation of these systems to the challenges and needs of the coming decades of the 21 st century. It is likely that one of these challenges will 
be the aforementioned "colonization" of space, but also possible, difficult to predict crises, which make take on a hybrid nature (e.g. health and environmental crisis or economic and political crisis). It cannot be ruled out that such a situation will generate other types of crises, including military ones.

The COVID-19 pandemic has shown, even more clearly than the financial crisis from the beginning of the 21 st century, the meaning of the term "risk civilization", as well as the necessary competences that individuals and legal entities should acquire to face the challenges ahead. The great challenge of our race, which is the conquest of space, will make this problem even more evident. But to what extent is mankind prepared for it? The relationships between the health of individuals and social groups and other spheres of life and activity of individuals and legal entities are easier to understand when the notions of health safety and health safety culture, as well as the health safety system, are used. Unfortunately, before the pandemic, these problems were mainly dealt with in a theoretical sense, using the narrow, conventional sense of these concepts. The consequences of this became evident with the recent outbreak of the pandemic.

One of the major weaknesses of safety systems, as well as individuals and legal entities operating in them, which has been observed during the COVID-19 pandemic, is a conventional way of thinking about safety that has been dominant for decades, or even centuries, but is no longer adequate to the needs. It can even undermine the effectiveness of ensuring safety in different areas and at various times. It can be assumed with a high degree of certainty that the pandemic-related experiences may contribute to abandoning by individuals and legal entities old habits related to narrow, negative and short-term thinking about safety. It cannot be ruled out that these experiences will also be conducive to the development of prospective and communal way of thinking in terms of anticipating and preventing various threats and the methods of individual and joint responses to such threats, with a balanced and sustainable development in mind. Before the outbreak of the COVID-19 pandemic, such a way of thinking was mostly theoretical. In practice, it seemed unrealistic due to the differences in the interests of various entities and the obsolescence of education systems. This contributed to the unnecessary "preservation" of the elements of safety culture, including health safety culture, which were not adequate to contemporary needs.

In order to introduce the necessary changes in this respect, improvements in the legal regulations and the education system are required. The reforms of these two systems should mainly take into account the fact that in the coming decades of the 21 st century it will no longer be enough to be able to search for information and use it efficiently in everyday life. 
The primary goal of education should be dissemination of knowledge and wisdom. The insights gained during the pandemic show that wisdom should not be understood as something abstract, as schools and universities often show it. Wisdom in its simplest form, like the proverbial "seed", should be the starting point for the education process at home, at schools and universities. The COVID-19 pandemic has exposed a significant shortage of wisdom of many individuals and legal entities, regardless of the country. It came as no surprise, taking into account that only a few centres in the world deal with the study of the phenomenon of wisdom ${ }^{29}$. Perhaps for this reason, this subject is almost non-existent in academic curricula, even at renowned universities.

\footnotetext{
${ }^{29}$ Research on the phenomenon of wisdom is carried out in several countries by: R. Sternberg et al. at Yale University and Cornell Universiy in the USA; in Berlin by P. Baltes et al.; M. Ardelt and her students at the Univesity of Florida, R. Walsh of the Univesity of California, Irvine et al., as well as: Ch. Peterson and M. E. P. Seligman and other (as in: Łukaszewski, 2018). For the purposes of this article, wisdom is understood as the ability to use information and knowledge and other types of resources to achieve worthy goals, skillfully combining common good with personal needs and interests.
} 


\section{References:}

Aleksandrowicz, J. (1972) 'W poszukiwaniu definicji zdrowia', Studia Filozoficzne, 9, pp. 2131.

Beck, U. (2002) Społeczeństwo ryzyka. W drodze do innej nowoczesności. Warszawa: Wydawnictwo Scholar.

Beck, U. (2012) Społeczeństwo światowego ryzyka. W poszukiwaniu utraconego bezpieczeństwa. Warszawa: Wydawnictwo Scholar.

Cederström, C., Spicer A. (2016) Pętla dobrego samopoczucia. Warszawa: Wydawnictwo PWN.

Cieślarczyk, M., Filipek, A., Świderski, A.W. \& Ważniewska, J. (2011) Wybrane problemy bezpieczeństwa zdrowotnego w Polsce. Siedlce: Wydawnictwo Uniwersytetu Przyrodniczo-Humanistycznego.

Cieślarczyk, M. (Ed.). (2015) Kultura bezpieczeństwa nr 3-4/2015. Siedlce: Wydawnictwo Uniwersytetu Przyrodniczo-Humanistycznego.

Cieślarczyk, M. (1997) Psychospołeczne i organizacyjne elementy bezpieczeństwa i obronności. Warszawa: Wydawnictwo Akademii Obrony Narodowej.

Cieślarczyk, M. \& Kołodziejczyk, A. (2019) Czynnik X. Morale w życiu osobistym, w działalności społecznej i zawodowej. Warszawa: Wydawnictwo Difin.

Cieślarczyk, M. (2006) Kultura bezpieczeństwa i obronności. Siedlce: Wydawnictwo Uniwersytetu Przyrodniczo-Humanistycznego.

Cieślarczyk, M., Trzpil, I.A., \& Zbroszczyk D. (2017) Bezpieczeństwo zdrowotne w Polsce. Uwarunkowania personalne i strukturalne. Siedlce: Wydawnictwo Uniwersytetu Przyrodniczo-Humanistycznego.

Clark J., Henderson J. (eds.). (2015) Community Health. Churchill Livingston. New York: Churchill Livingston.

Davidson, E., J., \& Sternberg, R. J. (1998) 'Smart problem solving: How metacognition helps', in D. J. Hacker, J. Dunlosky, \& A. C. Graesser (eds.), Metacognition in eductaional theory and practice. USA: Lawrence Erlbaum, pp. 47-68.

Doroszewicz, S. (2014) 'The method of classification of consumer attitude accessibility in relation to inherent product features', Polish Journal of Natural Sciences. Warszawa, 29(2).

Erikson, E.H. (1980) Identity and the Life Cycle. New York-London: Mass Market.

Fieschi, M. (2018) Health Data Processing. Academic Press.

Frei, D. (1977) Sichercheit. Grundfragen der Welt. Stuttgard: Verlag W. Kolhammer.

Giddens, A. (2010) Nowocześność i tożsamość. „Ja” i społeczeństwo w epoce późnej nowoczesności. Warszawa: Wydawnictwo Naukowe PWN.

Heszen-Niejodek, I., \& Broome, A. K., (1991) Rozwój zastosowań psychologii do obszaru zdrowia i choroby, Przeglad Psychologiczny, 34(1), pp. 57-77.

Jessel, D., \& Moir, A. (2014) Płeć mózgu. O prawdziwej różnicy między kobietą a mężczyzną. Warszawa: Państwowy Instytut Wydawniczy.

Korporowicz, V. (ed.). (2015) Zarządzanie Progresywne zdrowiem. Kierunki, strategie, metody. Warszawa: Wolters Kluwer Polska.

Koźmiński, A. K., (2012). Zarządzanie w warunkach niepewności. Podręcznik dla zaawansowanych. Warszawa: Wydawnictwo Naukowe PWN.

Krieger, N. (2001) 'Theories for social epidemiology in the 21st century: an ecosocial perspective', International Journal of Epidemiology, 30(4), pp. 668-677. doi:10.1093/ije/30.4.668

Kumar, A., \& Elhoseny, S. M. (2020) Intelligent Data Security Solutions for e-Health Applications. Academic Press. Elsevier 2020. 
Kumpfer, K. L., \& Turner, C. W. (1990) 'The social ecology model of adolescent substance abuse: Implications for prevention', International Journal of the Addictions, 25(4-A), 435-463. https://doi.org/10.3109/10826089009105124

Lytras, M., \& Sarirete, A. (2019) A Smart Healthcare Primer. Academic Press. Elsevier.

Łukaszewski, W. (2018) Mądrość i różne niemądrości. Sopot: Wydawnictwo Smak Słowa.

Maler K-G., \& Vincent J. (2005) Handbook of Environmental Economics. North Holland: Elsevier.

McCrie, R. (2015) Security, Operations Management. Amsterdam: Butterworth-Heinemann.

McIsaac, J. (2006) Hospital Preparation for Bioterror. Amsterdam: Academic Press.

Mintzberg, H. (1994) 'The rise and fall of strategic planning', Harvard Business Review, 72(1), pp. 107-114.

Mischel, W., Cantor, N., \& Feldman, S. (1996) 'Principles of self-regulation: The nature of willpower and self-control', Social psychology: Handbook of basic principles, (pp. 329-360). New York, NY, US: The Guilford Press.

Oetting, E. R., \& Donnermeyer, J. F. (1998) 'Primary Socialization Theory: The Etiology of Drug Use and Deviance', Substance Use \& Misuse, 33(4), pp. 995-1026. doi:10.3109/10826089809056252.

Piontek, B., \& Macha, K. (2016) 'Kategoria „zdrowie” i „choroba” i ich implikacje dla zarządzania systemem ochrony zdrowia', Nierówności Społeczne a Wzrost Gospodarczy, 48 (4).

Prettner, K., \& Bloom, D. (2020) Automation and Its Macroeconomic Consequences. Academic Press.

Puchalski, K., \& Korzeniowska, E. (eds.) (2017) Promocja zdrowia w zakładzie pracy: wsparcie dla zdrowego odżywiania się i aktywności fizycznej pracowników. Łódź: Instytut Medycyny Pracy im. prof. J. Nofera.

Purpura P. (2013) Security and Loss Prevention. Butterworth-Heinemann.

Richardson, H. A., Simmering, M. J., \& Sturman, M. C. (2009) Cornell University. School of Hospitality Administration. A tale of three perspectives: Examining post hoc statistical techniques for detection and correction of common method variance. Available at: http://scholarship.sha.cornell.edu/articles/104.

Roper, C. (1999) Risk Management for Security Professionals. Butterworth-Heinemann.

Senge, P. M. (2012) Piąta dyscyplina. Warszawa: Wolters Kluwer Polska.

Sennewald, Ch. (2011) Effective Security Management. Butterworth-Heinemann.

Sethumadhavan A., \& Sasangohar F. (2020) Design for Health. Academic Press.

Sethumadhavan, A., \& Sasangohar, F. (Eds.). (2020) Design for Health: Applications of Human Factor. Academic Press. Elsevier.

Stańczyk, J. (1996) Współczesne pojmowanie bezpieczeństwa. Warszawa: Instytut Studiów Politycznych PAN.

Sygit, M. (2017) Zdrowie publiczne. Warszawa: Wolters Kluwer Polska.

Tobiasz-Adamczyk, B. (2008) 'Elementy epidemiologii społecznej w programie nauczania epidemiologii w przed dyplomowym kształceniu studentów medycyny', Problemy Higieny i Epidemiologii, 89(2), pp. 178-182.

Trzebiatowski, J. (2011) 'Jakość życia w perspektywie nauk społecznych i medycznych systematyzacja ujęć definicyjnych', Hygeia Public Health, 46(1), pp. 25-31.

Wysocki, M. I., \& Cianciara, D. (2006) 'Koncepcja bezpieczeństwa zdrowotnego - panaceum czy placebo', Problemy higieny i epidemiologii, 87(2). pp. 79-82.

York, T., \& MacAlister, D. (2015) Hospital and Healthcare Security. ButterworthHeinemann.

Zaheer A. (2020) Surveying the COVID-19 Pandemic and Its Implications. Academic Press. Elsevier. 
Zalewska, M. (2012) 'Analiza wybranych wskaźników zdrowia publicznego w świetle strategii zrównoważonego rozwoju w krajach UE', Problemy Zarządzania, 11(41), pp. 53-71. 